after arrival in the Federated Malay States subtertian malaria set in, and six months after arrival he went into the European hospital of the State, complaining of swelling of the left leg and a large "bruise." There was no history of injury and he was discharged in 11 days. A fortnight after his discharge from hospital a second attack of malaria was experienced. Ten months after his arrival in this country he had a third attack of malaria. Then one month after this he returned to the European hospital, as his right leg went "black" and was swollen and painful. There was no history of injury. A diagnosis of scurvy was made. As the patient had nausea at the sight of soup, meat, \&c., and vomited if he tried to eat them, he drank lime squashes. He then came under my care, with a view to his being sent home. The patient was bronzed, but had lost $1 \frac{1}{2}$ st. in weight lately. The right leg was still swollen and discoloured about the ankle. Pressure on the tibia was very painful. The heart, chest, \&c., were clear. Hæmoglobin, 70 per cent. (Tallquist). No parasites in blood. Red blood corpuscles, 3,800,000; white blood corpuscles, 25,000. Urine and fæces, normal.

The patient lived with me for over a week, and as I had no porridge prepared he had to eat "at" whatever was going, and soon could take soup, potatoes, rice pudding, and very little green vegetables and a banana. He quickly improved and was sent to another estate, where there is a resident doctor. He did light work, but soon made porridge his chief article of diet again. In a month he had his fourth attack of subtertian malaria and returned to my care. Hæmoglobin, 65 per cent.; red blood corpuscles, 3,200,000; white blood corpuscles, 25,000. Having scratched a mosquito bite his right leg quickly swelled up and became septic, and when this had healed he returned to England.

This case has two or three points of interest. 1. A man living on practically nothing but porridge without any apparent cause. 2. Scurvy amongst Europeans is extremely rare in the Federated Malay States. I can hear of no other case. 3. The fact that he kept fairly fit so long. I take it that he would probably never have got "scurvy" if he had been able to obtain fresh milk. Fresh milk is very hard to obtain here, and when one has once seen a cow milked one feels much happier with the tinned variety. Also, brown bread is difficult to obtain and does not seem to be made to any extent by the native bakers. - I am, Sir, yours faithfully,

Kuala Lumpur, F.M.S. R. MCC. LINNELL.

\section{THE COUNCIL ELECTION AT THE ROYAL COLLEGE OF SURGEONS OF ENGLAND.}

To the Editor of THE LANCET.

SIR,-May I through the medium of your columns thank those gentlemen who roted for me in the recent election to the College Council? At the same time, I would like to take this opportunity to make it distinctly understood that I dissociate myself entirely from the very undiplomatic letter to which Mr. Percy Dunn takes exception in your issue of July $4 \mathrm{th}$. His complaint as to its tone is very justifiable, and its terms are calculated to alienate the cause of the Members and to put back the realisation of their claims.

When I seek election next year I shall reply to the questions sent me with this experience well in memory.

I am, Sir, yours faithfully,

Queen Anne-street, W., July 7th, 1914. MACLEOD YEARSLEY.

\section{THE BACTERIOLOGICAL EXAMINATION OF MILK.}

To the Editor of THE LANCET.

SIR,-I am glad that a distinguished bacterio. logist in the person of Professor R. T. Hewlett has come forward to point out in your issue of July 4th (p. 44) the fallacies inherent in the quantitative enumeration of bacteria in milk.

At the Infants Hospital, Vincent-square, S.W., the milk coming from the hospital farm and from other sources is examined daily, and I have long been of the opinion that the bacterial count method is of little value. Especially is this so when milks are examined in different laboratories and the results are compared. The difference in the precise method and in the media employed (even the slight differences in the preparation by competent persons of the same medium), and many other factors, result in all kinds of serious error. Of the greatest im. portance is the fact that the milk with the higher count may be a much better milk than that with the lower. Thus, we find that A contains 55,000 bacteria per c.c., while B only contains 14,000. But when we come to our observations in regard to (1) time of curdling at $19^{\circ} \mathrm{C}$. and $38^{\circ} \mathrm{C}$.; (2) development of acidity at $38^{\circ} \mathrm{C}$., (3) character of curd formation-gas production or otherwise, (4) nature of bacteria developing in the milk at $19^{\circ} \mathrm{C}$. and $38^{\circ} \mathrm{C}$, we find that $A$ is a much better milk than B, for the changes in A compare more closely with the changes occurring in a milk taken directly from the cow under strict precautions than do those in B. One method is of great value -the microscopical examination of the centrifu. galised deposit suitably stained. By this method an experienced observer can obtain information of the greatest practical importance. Not only can the number of bacteria be approximately estimated, but important information can be obtained with regard to the nature and probable source of any contamination. Thus, Gram-negative bacilli generally indicate colon organisms and consequently manurial contamination. Dust from dirty fodder can be recognised both by the general débris and by the presence of moulds. The cellular elements in the milk are readily recog. nised and early warning of mastitis may be forthcoming. An interesting point is that in the case of a contaminated milk the observer is often able to make a prognosis in regard to the behaviour of the milk when submitted to the above-mentioned tests. If this prognosis proves to be correct the case against the milk is a strong one. The great practical value of the method is its rapidity. Within half an hour of the receipt of the milk the examination of the centrifugalised deposit can be completed, and consequently, in the case of any defect in quality, we are able immediately to telephone to the farm, at the same time indicating the probable source of the contamina. tion. It is important that the centrifuge should be of large capacity, so that the samples of milk may be sufficiently ample to be representative, and we have recently installed Professor S. Delépine's centrifuge as with this instrument over $1 \frac{1}{2}$ litres can be dealt with at one time, while owing to its 
high speed (at 5000 revolutions-over four miles a minute) the usual time of centrifugalisation is much shortened. I am, Sir, yours faithfully,

Harley-street, W., July 4th, 1914. RALPH VINCENT.

\section{TOUCHING FOR THE KING'S EVIL.}

To the Editor of THE LANCET.

SIR,-A second letter upon this subject from Dr. F. Parkes Weber having appeared in your columns on June 27th, may I be excused for taking up my pen at his request in the hope of partially replying to some of the questions put forth by him?

He asks firstly: "Are the old well-cast specimens [of that much-discussed token, Medallic Illustrations, Plate xxxiii., 23] to be regarded all of them as forgeries of the period for the use of ill-disposed persons to gain fraudulent access to the king?' To this I reply that the wording of the document mentioned by me in my last letter, and which will be published in full in the British Numismatic Journal, lies open to a dual interpretation. The passage reads: "Whereas wee are informed by our Serjeant-Chirurgion, that there hath been a great abuse comitted by dissolute and ill-disposed People, who to gaine the Gold only, have counterfeited his tokens, which were cast in a mold made by a Freemason, wherein we have not only been deceaved of many Angells," \&c. The grammar, if correct-a doubtful assumption at that periodshould mean that the original tokens were cast by the Freemason. Against this is the fact that both struck and cast pieces of the better class exist, but it was no uncommon practice, as we notice in the case of badges and medals of stuart times, to make one pair of dies, and after striking from them a number of specimens, to multiply these by casting. We might also read the passage as meaning that the Freemason was the forger, but this is immaterial, for fraudulent casts had clearly been made, and some poor examples seem to fit into this category.

Dr. Parkes Weber's second question relates to the fact that we have seen no tokens the size of an angel, and suggests that this condition may have been abandoned. But this I venture to think was unlikely as the change of size would be material in distinguishing the new token from the old, no mention being made of an alteration in design. We might account for the above rarity by the injunction that the tally should be returned to the mintmaster after use, "whereby he may know what number of Angells have bin expended." Naturally under the Commonwealth, "touching" being no longer in vogue, the officials would melt down the metal lying idle. Some pieces, however, should have escaped, being unredeemed, and unless such be found this point must remain " non proven." I am far from suggesting that the other pieces referred to by Dr. Parkes Weber were not made for a similar purpose of admission, but might they not be intended for the coronation or some other ceremony, inasmuch as the legends are less appropriate to "healing" than that of the token which we have discussed ?

I did, however, in my lecture in May before the British Numismatic Society go so far as to mention the possibility that the "Soli Deo Gloria" pattern halfpenny-for as such its exact weight induced Mr. Montagu to class it (see Montagu's "Copper Coins of England," p. 41, No. 1)-of the second Charles, might be a ticket of admission to his "touching" séances. It is not very rare and exists in various combinations of metals, a not un. likely precaution to regulate the number of persons coming in successive weeks, for the "healings" under this king were very frequent. Mr. McLachlan suggested that it might be the touchpiece of Charles II.'s exile, and put forth in the Numismatist for March, 1912, excellent arguments for this attribution, which we have no documentary evidence to disprove.

Lastly, Dr. Parkes Weber refers to the silver touchpiece in the Wellcome Historical Medical Museum, reading IAC. 8 instead of IAC.3. This is an example highly interesting to the student, not only from its rarity, but for historical associations, agreeing as it does in other respects with the type used by James Francis Edward during his exile in France, whilst this Scottish title brings to mind the dies, bearing date 1716, engraved for the King de Jure, as Jacobus VIII., and intended for the coinage of the northern kingdom, had his second invasion proved successful.

I am, Sir, yours faithfully,

Belgrave-square, S.W., June 30th, 1914. HELEN FARQUHAR.

\section{To the Editor of THE LANCET.}

SIR,-I regret a misstatement in my brief note on the above subject in your last issue. The coin alluded to is not the one that caught my attention in the Hodgkin collection: my informant and I misapprehended one another.

I am, Sir, yours faithfully,

London, July 6tb, 1914. RAYMOND CRAWFURD.

\section{LATIN FOR MEDICAL STUDENTS. To the Editor of THE LANCET.}

SIR,-I was interested in your annotation on Latin for medical students in THE LANCET of June 27th. I heartily endorse your remark that "the student who has learned Latin will find his examinational career much easier." The fact is, that unless the teaching of classics be so reformed as not to clash with conditions which have vastly altered in the last 25 years, it will have to go. The modern boy can have his interest in Latin awakened if after the necessary grammatical preliminaries he is assisted to read intelligently the more interesting authors. He ought to read far more and do less of putting English into Latin. The master should assist him in class to translate unprepared passages, while he explains all the historical and antiquarian matter necessary to render the author intelligible. Such mysteries as the ethic dative, anacoluthon, and oxymoron are best avoided. The practice of prescribing a set book for an elementary examination is an abomination which London University has done its best to end. Boys who are instructed in class how to tackle passages they have never seen before are bound to get a better grip of Latin than those who work up a set book and notes parrot fashion. Unless the Universities of Oxford and Cambridge can be got to abolish compulsory Greek for those destined for mathematical, medical, or scientific careers the whole fabric of the classics as a valuable educational medium will be crushed under the juggernaut car of modern hustle. Latin verse composition for the average boy is a hideous waste of time, while Greek iambics are something worse. I well remember as a young boy being dragged through Book II. of the Gallic War with 